ISSN 1678-3921

Journal homepage: www.embrapa.br/pab

For manuscript submission and journal contents, access: www.scielo.br/pab
Adriele Nayara Dias Ishizuka (1) (D), Marco Antônio Gonzales de Carvalho(1) (D), Robert Guaracy Aparecido Cardoso $\operatorname{Araujo}^{(2 \otimes)}$ (iD,

Juliana Célia Denadai ${ }^{(1)}$ (D), Guilherme Emygdio Mendes Pimenta(1) (D), Maria Márcia Pereira Sartori ${ }^{(3)}$ (iD and Vladimir Eliodoro Costa(1) (D)

(1) Universidade Estadual Paulista Júlio de Mesquita Filho, Departamento de Física e Biofísica, Instituto de Biociências, Centro de Isótopos Estáveis Ambientais em Ciências da Vida, CEP 18618-970 Botucatu, SP, Brazil. E-mail: adriele_drik@hotmail.com, gonzalezmarco@hotmail.com, denadaijc@gmail.com, gmpimenta@zootecnista.com.br, vladimir.costa@unesp.br

(2) Universidade Estadual Paulista Júlio de Mesquita Filho, Faculdade de Medicina Veterinária e Zootecnia, Campus de Botucatu, Rua Prof. Doutor Walter Mauricio Correa, s/no, CEP 18618-681 Botucatu, SP, Brazil. E-mail: robertzootecnista@gmail.com

(3) Universidade Estadual Paulista Júlio de Mesquita Filho, Faculdade de Ciências Agronômicas, Fazenda Experimental Lageado, CEP 18618-970 Botucatu, SP, Brazil.

E-mail:mmpsartori@fca.unesp.br

$\bowtie$ Corresponding author

Received

April 04, 2019

Accepted

March 16, 2020

How to cite

ISHIZUKA, A.N.D.; CARVALHO, M.A.G. de; ARAUJO, R.G.A.C.; DENADAI, J.C.; PIMENTA, G.E.M.; SARTORI, M.M.P.; COSTA, V.E. Traceability of animal meals in quail eggs using carbon and nitrogen stable isotopes. Pesquisa Agropecuária Brasileira, v.55, e01394, 2020. DOI: https://doi.org/10.1590/S1678-3921. pab2020.v55.01394.

\section{Traceability of animal meals in quail eggs using carbon and nitrogen stable isotopes}

\begin{abstract}
The objective of this work was to detect the inclusion of animal meal in Japanese quail (Coturnix coturnix japonica) diets, by analyzing eggs and their fractions (albumen and yolk) through the technique of carbon $\left({ }^{13} \mathrm{C} /{ }^{12} \mathrm{C}\right.$ ) and nitrogen $\left({ }^{15} \mathrm{~N} /{ }^{14} \mathrm{~N}\right)$ stable isotopes. Four hundred and thirty-two Japanese quails, 45-day-old females, were distributed in a completely randomized experimental design, in eight treatments: T1, strictly vegetable diet (VEG), with corn (Zea mays) and soybean (Glycine max) meal; T2, bovine meat and bone meal (BM); T3, poultry viscera meal (OM); T4, feather meal (FM); T5, $\mathrm{BM}+\mathrm{OM}$; T6, BM+FM; T7, OM+FM; and T8, BM+OM+FM. Sixteen eggs were randomly collected from each treatment - eight for whole egg analysis and eight for separate yolk and albumen analyses. To determine the turnover rate, the exponential isotope dilution model was used. The application of $\mathrm{C}$ and $\mathrm{N}$ stable isotopes allows identifying the use of animal meal in coded diets through the analysis of whole eggs and their fractions, which suggests that this technique is a promising tool for the traceability and certification of products of animal origin.
\end{abstract}

Index terms: Coturnix coturnix japonica, bovine meal, certification, feather meal, poultry viscera meal.

\section{Rastreabilidade de farinhas de origem animal em ovos de codornas por meio de isótopos estáveis de carbono e nitrogênio}

Resumo - O objetivo deste trabalho foi detectar a inclusão de farinha de origem animal em dietas de codornas japonesas (Coturnix coturnix japonica), ao analisar os ovos e suas frações (albúmen e gema) por meio da técnica de isótopos estáveis de carbono $\left({ }^{13} \mathrm{C} /{ }^{12} \mathrm{C}\right)$ e nitrogênio $\left({ }^{15} \mathrm{~N} /{ }^{14} \mathrm{~N}\right)$. Quatrocentas e trinta e duas codornas japonesas, fêmeas com 45 dias de idade, foram distribuídas em delineamento experimental inteiramente casualizado, em oito tratamentos: T1, dieta estritamente vegetal, com farinha de milho (Zea mays) e soja (Glycine max) (VEG); T2, farinha de carne e ossos bovinos (BM); T3, farinha de vísceras de aves (OM); T4, farinha de penas (FM); T5, $\mathrm{BM}+\mathrm{OM}$; T6, BM+FM; T7, OM+FM; e T8, BM+OM+FM. Foram colhidos aleatoriamente 16 ovos de cada tratamento - oito para análise de ovo inteiro e oito para análise separada de gema e albúmen. Para determinar a taxa de "turnover", utilizou-se o modelo exponencial de diluição isotópica. A aplicação de isótopos estáveis de $\mathrm{C}$ e $\mathrm{N}$ permite identificar o uso de farinha de origem animal em dietas codificadas, por meio da análise dos ovos inteiros e de suas frações, o que sugere que esta técnica é uma ferramenta promissora para a rastreabilidade e a certificação de produtos de origem animal.

Termos para indexação: Coturnix coturnix japonica, farinha bovina, certificação, farinha de penas, farinha de vísceras de aves. 


\section{Introduction}

In Brazil, the quail herd grew in 2018, reaching the mark of 16.8 million heads, an increase of $3.90 \%$, compared with 2017, while egg production decreased $2.1 \%$ (IBGE, 2019). In the country, most quail are farmed for egg production. Japanese quail (Coturnix coturnix japonica) are exclusively used to produce eggs, while common quail (Cortunix coturnix coturnix) are used for egg and meat production. It appears that, in general, quail produce more eggs up to 60 weeks of age, due to their sexual precocity in the early stages of rearing (Bertechini, 2010).

In some countries, because of the greater availability and lower cost of ingredients of animal origin, a common practice, in poultry farming, is replacing expensive ingredients, such as soybean [Glycine max (L.) Merr.] meal and dicalcium phosphate, with animal meals, an alternative source of calcium, phosphorus, and protein (Wang \& Parsons 1998; Hendriks et al., 2002). This adds to the current concerns regarding food safety, related to transgenic foods, food adulteration and mislabeling, and worldwide incidents such as mad cow disease, avian influenza, swine influenza, and dioxin contamination (Gottmann, 2008; Bottero \& Dalmasso, 2011).

In this scenario, traceability systems have been implemented to try to ensure the safety of animal products to the consumers, in response to the requirements imposed by the European Union in regulation 1069/2009 of the European Parliament and Council (European Union, 2009), which banned the import of products derived from animals fed byproducts from animals of the same species.

Several analytical methods have been used to test food safety, among which is isotope ratio mass spectrometry. This method has been successfully used to authenticate feeding diets because the stable isotope signatures in the products derived from animals reflect the stable isotope composition of their feed (Prache et al., 2005). Stable isotopes have been used in different studies for the traceability of animal products (Vinci et al., 2013), including egg traceability and authenticity (Rock, 2012; Rock et al., 2013), bird diet inference by the egg fraction analysis (Herzka et al., 2013), and differentiation among egg production systems (Rogers, 2009).

Previous studies have shown that stable isotopes can detect, via eggs, the inclusion of bovine meat and bone meal in the diets of Japanese quail and in broiler feed (Mori et al., 2007, 2008, 2013; Oliveira et al., 2010). However, there are no known traceability studies on other animal meals, such as poultry offal meal and feather meal, added to quail diets and assessed through egg analyses.

The objective of this work was to detect the inclusion of animal meal in Japanese quail diets, by analyzing eggs and their fractions (albumen and yolk) through the technique of carbon $\left({ }^{13} \mathrm{C} /{ }^{12} \mathrm{C}\right)$ and nitrogen $\left({ }^{15} \mathrm{~N} /{ }^{14} \mathrm{~N}\right)$ stable isotopes.

\section{Materials and Methods}

The experiment was conducted in the bioclimatic chamber at the Lageado experimental farm of Faculdade de Medicina Veterinária e Zootecnia of Universidade Estadual Paulista Júlio de Mesquita Filho (Unesp), located in the municipality of Botucatu, in the state of São Paulo, Brazil. The study was approved by the ethics committee of animal use of Faculdade de Medicina Veterinária e Zootecnia of Unesp (protocol number 143/2013).

A total of 432 45-day-old female Japanese quail (Coturnix japonica) were obtained from a commercial incubator and housed in $0.40 \times 0.50-\mathrm{m}$ experimental galvanized wire cages, with a frontal feeder and nipple drinkers; all animals were previously vaccinated against infectious bursal disease, Marek's disease, and Bouba's disease. Temperature and ventilation were controlled to maintain the thermal comfort zone (thermoneutral temperature) throughout the farming period. A 17-hour daylight program, using artificial illumination, was adopted.

The experimental design was completely randomized with eight treatments and eight replicates. The treatments were: T1, a strictly vegetable control diet, with corn (Zea mays L.) and soybean meal; T2, bovine meat and bone meal (BM); T3, poultry offal meal (OM); T4, feather meal (FM); T5, BM+OM; T6, BM+FM; T7, OM+FM; and T8, BM+OM+FM (Table 1). Nutritional requirements were established according to Rostagno (2011). The diets were formulated to provide similar levels of energy, protein, phosphorus, and amino acids (methionine, cystine, and lysine) (Table 2).

The experiment started when the quail were 45 days old; from then on, they were fed for another 45 
days. At the end of experimental period, 16 eggs were randomly collected from each treatment group, eight for sampling of the whole egg (yolk + albumen) and eight for individual sampling of the yolk and albumen.
The eggs were frozen at $-18^{\circ} \mathrm{C}$. For the isotopic analyses, performed at Centro de Isótopos Estáveis Ambientais em Ciências of Unesp, the samples were freeze-dried in the L108 equipment (Liobras, São Carlos, SP, Brazil)

Table 1. Composition of the experimental diets fed to the Japanese quail (Coturnix japonica).

\begin{tabular}{|c|c|c|c|c|c|c|c|c|}
\hline \multirow{2}{*}{$\begin{array}{l}\text { Ingredient }^{(1)} \\
(\%)\end{array}$} & \multicolumn{8}{|c|}{ Experimental $\operatorname{diet}^{(2)}$} \\
\hline & VEG & $\mathrm{BM}$ & $\mathrm{OM}$ & FM & $\mathrm{BM}+\mathrm{OM}$ & $\mathrm{BM}+\mathrm{FM}$ & $\mathrm{OM}+\mathrm{FM}$ & $\mathrm{BM}+\mathrm{OM}+\mathrm{FM}$ \\
\hline Corn grain & 57.99 & 60.92 & 61.43 & 62.61 & 61.77 & 62.15 & 62.24 & 62.01 \\
\hline Soybean meal & 31.16 & 26.98 & 25.50 & 23.52 & 25.67 & 24.72 & 24.46 & 25.17 \\
\hline BM & - & 4.00 & - & - & 2.50 & 2.50 & - & 2.50 \\
\hline $\mathrm{OM}$ & - & - & 4.00 & - & 2.00 & - & 2.00 & 1.00 \\
\hline Feather meal & - & - & - & 4.00 & - & 2.00 & 2.00 & 1.00 \\
\hline Soybean oil & 1.33 & 0.38 & - & 0.27 & - & 0.20 & 0.06 & 0.08 \\
\hline Limestone & 7.20 & 6.62 & 7.10 & 7.24 & 6.80 & 6.87 & 7.18 & 6.83 \\
\hline Dicalcium phosphate & 1.20 & - & 0.70 & 1.14 & 0.18 & 0.40 & 0.92 & 0.29 \\
\hline DL-methionine & 0.23 & 0.23 & 0.21 & 0.24 & 0.22 & 0.24 & 0.23 & 0.23 \\
\hline L-lysine & 0.24 & 0.27 & 0.23 & 0.34 & 0.26 & 0.31 & 0.29 & 0.29 \\
\hline Salt & 0.35 & 0.30 & 0.31 & 0.34 & 0.30 & 0.31 & 0.32 & 0.30 \\
\hline Vitamin premix ${ }^{(3)}$ & 0.15 & 0.15 & 0.15 & 0.15 & 0.15 & 0.15 & 0.15 & 0.15 \\
\hline Mineral premix $^{(4)}$ & 0.15 & 0.15 & 0.15 & 0.15 & 0.15 & 0.15 & 0.15 & 0.15 \\
\hline Kaolin & - & - & 0.22 & - & - & - & - & - \\
\hline Total & 100.00 & 100.00 & 100.00 & 100.00 & 100.00 & 100.00 & 100.00 & 100.00 \\
\hline
\end{tabular}

${ }^{(1)} \mathrm{BM}$, bovine meat and bone meal; and OM, poultry offal meal. (2)VEG, strictly vegetable control treatment, with corn (Zea mays) and soybean (Glycine max) meal; FM, feather meal; $\mathrm{BM}+\mathrm{OM}$, bovine meat and bone meal and poultry offal meal; $\mathrm{BM}+\mathrm{FM}$, bovine meat and bone meal plus feather meal; $\mathrm{OM}+\mathrm{FM}$, poultry offal meal plus feather meal; and $\mathrm{BM}+\mathrm{OM}+\mathrm{FM}$, bovine meat and bone meal plus poultry offal meal plus feather meal. ${ }^{(3)} \mathrm{Vitamin}$ premix assurance levels per kilogram of product: $100 \mathrm{mg}$ folic acid, $6 \mathrm{~g}$ pantothenic acid, $1 \mathrm{~g}$ butylated hydroxytoluene, $5 \mathrm{mg}$ biotin, $20 \mathrm{~g}$ niacin, 7.000 .000 IU vitamin A, $250 \mathrm{mg}$ vitamin B1, $6 \mathrm{~g}$ vitamin B12, $3 \mathrm{~g}$ vitamin B2, $150 \mathrm{mg}$ vitamin B6, 2.500.000 IU vitamin D3, $8 \mathrm{~g}$ vitamin E, and $1.2 \mathrm{mg}$ vitamin K3. ${ }^{(4)}$ Mineral premix assurance levels per kilogram of product: $50 \mathrm{~g}$ manganese, $40 \mathrm{~g}$ zinc, $30 \mathrm{~g}$ iron, $6 \mathrm{~g}$ copper, $400 \mathrm{mg}$ iodine, and $180 \mathrm{mg}$ selenium.

Table 2. Nutritional levels calculated for the experimental diets fed to the Japanese quail (Coturnix coturnix japonica).

\begin{tabular}{|c|c|c|c|c|c|c|c|c|}
\hline \multirow{2}{*}{$\begin{array}{l}\text { Nutritional } \\
\text { level }{ }^{(1)}\end{array}$} & \multicolumn{8}{|c|}{ Experimental $\operatorname{diet}^{(2)}$} \\
\hline & VEG & $\mathrm{BM}$ & $\mathrm{OM}$ & FM & $\mathrm{BM}+\mathrm{OM}$ & $\mathrm{BM}+\mathrm{FM}$ & $\mathrm{OM}+\mathrm{FM}$ & $\mathrm{BM}+\mathrm{OM}+\mathrm{FM}$ \\
\hline $\operatorname{ME}\left(\mathrm{kcal} \mathrm{kg}^{-1}\right)$ & 2,800 & 2,800 & 2,800 & 2,800 & 2,800 & 2,800 & 2,800 & 2,800 \\
\hline Crude protein (\%) & 19.00 & 19.00 & 19.00 & 19.00 & 19.00 & 19.00 & 19.00 & 19.00 \\
\hline Calcium (\%) & 3.10 & 3.10 & 3.10 & 3.10 & 3.10 & 3.10 & 3.10 & 3.10 \\
\hline Available phosphorus (\%) & 0.33 & 0.33 & 0.32 & 0.33 & 0.33 & 0.33 & 0.33 & 0.33 \\
\hline Crude fiber (\%) & 2.66 & 2.53 & 2.41 & 2.33 & 2.46 & 2.42 & 2.37 & 2.44 \\
\hline Methionine (\%) & 0.49 & 0.49 & 0.49 & 0.49 & 0.49 & 0.49 & 0.49 & 0.49 \\
\hline SAA $(\%)$ & 0.75 & 0.74 & 0.75 & 0.84 & 0.74 & 0.79 & 0.80 & 0.77 \\
\hline Lysine (\%) & 1.10 & 1.09 & 1.09 & 1.08 & 1.09 & 1.08 & 1.09 & 1.09 \\
\hline
\end{tabular}

${ }^{(1)} \mathrm{ME}$, metabolizable energy; and SAA, sulfur amino acids. ${ }^{(2)} \mathrm{VEG}$, strictly vegetable control treatment, with corn (Zea mays) and soybean (Glycine max) meal; BM, bovine meat and bone meal; OM, poultry offal meal; FM, feather meal; BM+OM, bovine meat and bone meal plus poultry offal meal; $\mathrm{BM}+\mathrm{FM}$, bovine meat and bone meal plus feather meal; OM+FM, poultry offal meal plus feather meal; $\mathrm{BM}+\mathrm{OM}+\mathrm{FM}$, bovine meat and bone meal plus poultry offal meal plus feather meal. Nutritional levels were calculated according to Rostagno (2011). 
for 48 hours. Eight samples of whole eggs and eight of yolk and albumen were packed individually in paper filters, soaked in diethyl ether, and defatted using the MA491 Soxhlet apparatus (Marconi Equipamentos para Laboratórios Ltda, Piracicaba, SP, Brazil) for 4 hours at $55^{\circ} \mathrm{C}$. The samples were placed in the MA035 forced-air oven (Marconi Equipamentos para Laboratórios Ltda, Piracicaba, SP, Brazil), at $50^{\circ} \mathrm{C}$ for 1 hour, in order to allow the volatilization of the residual ether.

Next, all samples and the diets of each treatment were placed in individual polycarbonate flasks with three stainless steel balls. The flasks were sealed and frozen in liquid nitrogen, at $-196^{\circ} \mathrm{C}$, and milled in the 2010 Geno/Grinder cryogenic mill (Spex SamplePrep, Metuchen, NJ, USA) at a frequency of $900 \mathrm{rpm}$ for 3 min. Afterwards, the diets were milled at a frequency of $900 \mathrm{rpm}$ for $10 \mathrm{~min}$. The ground egg samples were placed into tin capsules for the analysis of carbon and nitrogen (50-70 and 500-600 $\mu \mathrm{g}$, respectively), and the diets were weighed and put into tin capsules for the analysis of carbon and nitrogen (50-70 and 2,1002,200 $\mu$ g, respectively).

For isotopic ratio determination, the tin capsules were placed and burned in the Flash 2000 Elemental Analyzer (Thermo Fisher Scientific Inc., Bremen, Germany) to obtain $\mathrm{CO}_{2}$ and $\mathrm{N}_{2}$. The gases were separated in a gas chromatography column and analyzed in the Delta V Advantage isotope ratio mass spectrometer (Thermo Fisher Scientific Inc., Bremen, Germany). For ${ }^{13} \mathrm{C}$, the values of the isotopic ratios were expressed in delta $(\delta)$ per mil (\%) relative to the PeeDee Belemnite international standard, and, for ${ }^{15} \mathrm{~N}$, in atmospheric air nitrogen, according to the following general equation (Craig, 1953):

$[(\delta \mathrm{X})] \_((\text {sample, standard }))=\left(\left(\mathrm{R}_{\text {_sample }}-\mathrm{R}_{\text {_standard }}\right)\right) / \mathrm{R}_{\text {standard }}$,

where $\delta \mathrm{X}$ is the enrichment of the heaviest isotope of chemical element $\mathrm{X}(\mathrm{C}$ or $\mathrm{N})$ of the sample relative to the respective international standard; and $\mathrm{R}$ is the isotope ratio between the least and the most abundant isotope, for example ${ }^{13} \mathrm{C} /{ }^{12} \mathrm{C}$ and ${ }^{15} \mathrm{~N} /{ }^{14} \mathrm{~N}$.

The data were analyzed using the Minitab 16 statistical software (Minitab, Inc., State College, PA, USA). Isotopic data were subjected to the analysis of variance and to Tukey's test, at 5\% probability. Scatter plots were used to better visualize the obtained results.

\section{Results and Discussion}

The $\delta^{13} \mathrm{C}$ and $\delta^{15} \mathrm{~N}$ isotopic ratios of the animal meal treatments were similar ( $>0.05)$ to those of the strictly vegetable control (Table 3 ). However, differences were observed in the $\delta^{13} \mathrm{C}$ isotopic ratio of the egg, albumen, and yolk when animal meals were included in the diets.

Table 3. Means and coefficient of variation $(\mathrm{CV})$ of the carbon $\left(\delta^{13} \mathrm{C}\right)$ and nitrogen $\left(\delta^{15} \mathrm{~N}\right)$ isotopes in the diets $(\mathrm{n}=24)$, eggs $(\mathrm{n}=64)$, yolk $(\mathrm{n}=64)$, and albumen $(\mathrm{n}=64)$ of Japanese quail (Coturnix coturnix japonica) subjected to different treatments ${ }^{(1)}$.

\begin{tabular}{|c|c|c|c|c|c|c|c|c|c|}
\hline \multirow[t]{2}{*}{ Variable } & \multicolumn{8}{|c|}{ Treatment $^{(2)}$} & \multirow{2}{*}{$\begin{array}{l}\text { CV } \\
(\%)\end{array}$} \\
\hline & VEG & $\mathrm{BM}$ & $\mathrm{OM}$ & FM & $\mathrm{BM}+\mathrm{OM}$ & $\mathrm{BM}+\mathrm{FM}$ & $\mathrm{OM}+\mathrm{FM}$ & $\mathrm{BM}+\mathrm{OM}+\mathrm{FM}$ & \\
\hline \multicolumn{10}{|l|}{ Diet } \\
\hline$\delta^{13} \mathrm{C}$ & $-17.6 a$ & $-17.6 a$ & $-17.2 \mathrm{a}$ & $-17.0 \mathrm{a}$ & $-17.4 a$ & $-16.9 a$ & $-16.8 \mathrm{a}$ & $-17.6 a$ & 2.3 \\
\hline$\delta^{15} \mathrm{~N}$ & $1.1 \mathrm{a}$ & $1.4 \mathrm{a}$ & $1.4 \mathrm{a}$ & $1.6 \mathrm{a}$ & $1.5 \mathrm{a}$ & $1.6 \mathrm{a}$ & $1.6 \mathrm{a}$ & $1.3 \mathrm{a}$ & 13.7 \\
\hline \multicolumn{10}{|l|}{ Egg } \\
\hline$\delta^{13} \mathrm{C}$ & $-20.2 \mathrm{a}$ & $-19.3 b$ & $-19.1 b$ & $-19.1 b$ & $-19.1 b$ & $-19.1 b$ & $-19.4 b$ & $-19.4 b$ & 2.9 \\
\hline$\delta^{15} \mathrm{~N}$ & $3.7 \mathrm{a}$ & $4.3 b$ & $4.2 \mathrm{~b}$ & $4.3 b$ & $4.3 b$ & $4.3 b$ & $4.6 \mathrm{~b}$ & $4.7 b$ & 9.2 \\
\hline \multicolumn{10}{|l|}{ Albumen } \\
\hline$\delta^{13} \mathrm{C}$ & $-19.9 a$ & $-19.2 b$ & $-19.1 b$ & $-18.5 c$ & $-18.9 b c$ & $-19.0 b c$ & $-19.0 b c$ & $-19.0 b c$ & 2.5 \\
\hline$\delta^{15} \mathrm{~N}$ & $2.9 \mathrm{a}$ & $3.4 b$ & $3.8 \mathrm{bc}$ & $3.6 b$ & $3.6 \mathrm{~b}$ & $3.7 b c$ & $3.8 \mathrm{bc}$ & $4.1 \mathrm{c}$ & 11.7 \\
\hline \multicolumn{10}{|l|}{ Yolk } \\
\hline$\delta^{13} \mathrm{C}$ & $-20.3 a$ & $-19.0 b$ & $-19.0 b$ & $-18.6 b$ & $-18.9 b$ & $-18.9 b$ & $-18.9 b$ & $-19.0 b$ & 3.0 \\
\hline$\delta^{15} \mathrm{~N}$ & $4.5 \mathrm{a}$ & $4.6 \mathrm{ab}$ & $4.8 \mathrm{ab}$ & $4.9 \mathrm{ab}$ & $4.7 \mathrm{ab}$ & $4.7 \mathrm{ab}$ & $4.9 \mathrm{ab}$ & $5.1 \mathrm{~b}$ & 7.5 \\
\hline
\end{tabular}

${ }^{(1)}$ Means followed by equal letters, in the columns, do not differ by Tukey's test, at 5\% probability. ${ }^{(2)}$ VEG, strictly vegetable control treatment, with corn (Zea mays) and soybean (Glycine max) meal; BM, bovine meat and bone meal; OM, poultry offal meal; FM, feather meal; BM+OM, bovine meat and bone meal plus poultry offal meal; BM+FM, bovine meat and bone meal plus feather meal; OM+FM, poultry offal meal plus feather meal; and $\mathrm{BM}+\mathrm{OM}+\mathrm{FM}$, bovine meat and bone meal plus poultry offal meal plus feather meal. 
In all treatments, the $\delta^{13} \mathrm{C}$ of the egg, albumen, and yolk depleted in comparison with that of the diet, whereas there was an enrichment in the $\delta^{15} \mathrm{~N}$ of the egg, albumen, and yolk when compared with that of the diet.

The nitrogen-15 analyses of the egg and albumen samples showed a significant difference $(p<0.05)$ between the control (Table 3 and Figures 1 and 2) and the treatments with animal meals. This can be explained by the enrichment in nitrogen-15 that occurs for each rise in the trophic level (DeNiro \& Epstein, 1978). In yolk, enrichments in $\delta^{15} \mathrm{~N}$ were observed, with no differences between the vegetable treatment and those with animal meal (Table 3).

Because there was a similar isotopic enrichment across animal meal treatments, no significant differences were found in the egg isotopic analyses $(p>0.05)$. These results differ from those of Denadai et al. (2008), who reported no enrichment in eggs subjected to the OM treatment and no difference in relation to the control, despite verifying that the eggs from animals that received the BM, FM, OM+FM, and $\mathrm{BM}+\mathrm{OM}+\mathrm{FM}$ treatments were isotopically enriched.

Yolk allowed discriminating $(\mathrm{p}<0.01)$ between all the treatments with animal meal and the vegetable control (Figura 3). However, according to Denadai et

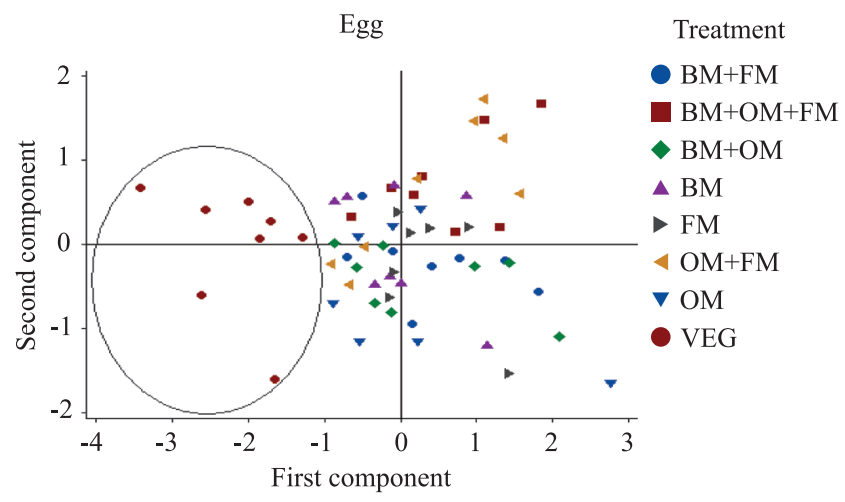

Figure 1. Scatterplot of the delta values of carbon-13 versus nitrogen-15 of the animal meal and vegetable treatments in 90-day-old eggs of Japanese quail (Coturnix coturnix japonica) fed experimental diets for 45 days. $\mathrm{BM}+\mathrm{FM}$, bovine meat and bone meal plus feather meal; $\mathrm{BM}+\mathrm{OM}+\mathrm{FM}$, bovine meat and bone meal plus poultry offal meal plus feather meal; $\mathrm{BM}+\mathrm{OM}$, bovine meat and bone meal plus poultry offal meal; BM, bovine meat and bone meal; FM, feather meal; $\mathrm{OM}+\mathrm{FM}$, poultry offal meal plus feather meal; OM, poultry offal meal; and VEG, strictly vegetal control treatment, with corn (Zea mays) and soybean (Glycine max) meal.

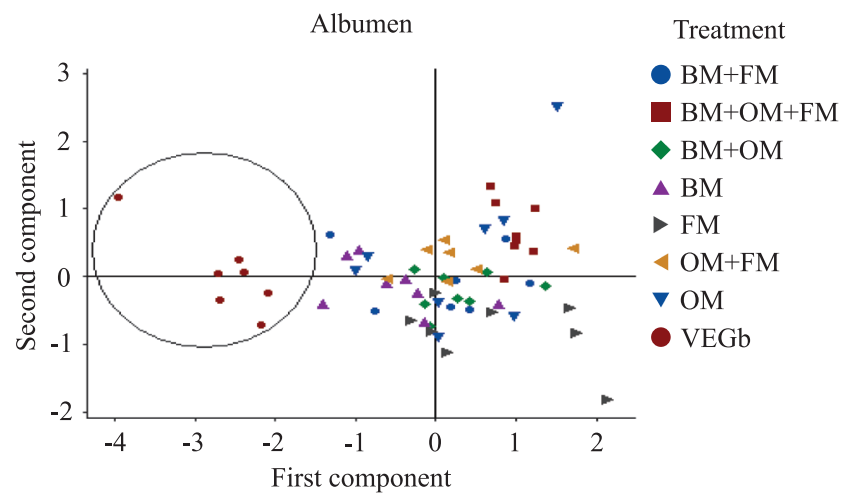

Figure 2. Scatterplot of the delta values of carbon-13 versus nitrogen-15 of the animal meal and vegetable treatments in the albumen of 90-day-old eggs of Japanese quail (Coturnix coturnix japonica) fed experimental diets for 45 days. $\mathrm{BM}+\mathrm{FM}$, bovine meat and bone meal plus feather meal; $\mathrm{BM}+\mathrm{OM}+\mathrm{FM}$, bovine meat and bone meal plus poultry offal meal plus feather meal; $\mathrm{BM}+\mathrm{OM}$, bovine meat and bone meal plus poultry offal meal; BM, bovine meat and bone meal; FM, feather meal; OM+FM, poultry offal meal plus feather meal; OM, poultry offal meal; and VEG, strictly vegetal control treatment, with corn (Zea mays) and soybean (Glycine max) meal.

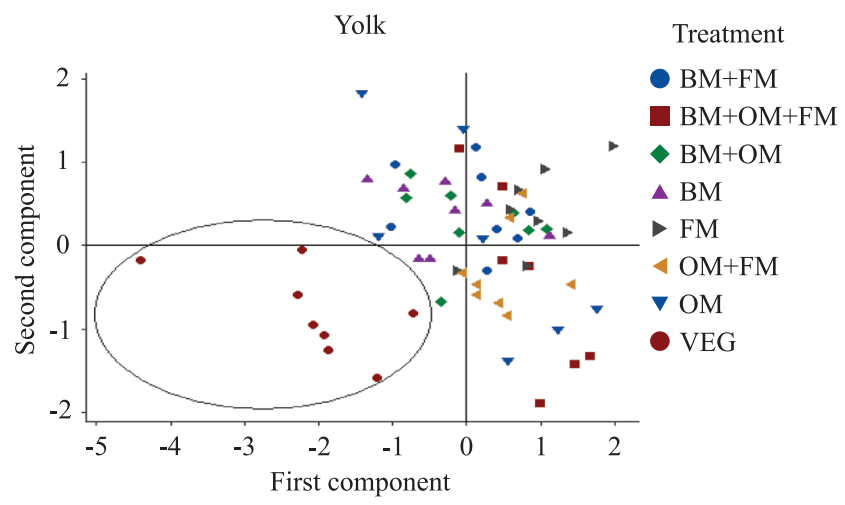

Figure 3. Scatterplot of the delta values of carbon- 13 versus nitrogen-15 of the animal meal and vegetable treatments in the yolk of 90-day-old eggs of Japanese quail (Coturnix coturnix japonica) fed experimental diets for 45 days. $\mathrm{BM}+\mathrm{FM}$, bovine meat and bone meal plus feather meal; $\mathrm{BM}+\mathrm{OM}+\mathrm{FM}$, bovine meat and bone meal plus poultry offal meal plus feather meal; $\mathrm{BM}+\mathrm{OM}$, bovine meat and bone meal plus poultry offal meal; BM, bovine meat and bone meal; FM, feather meal; OM+FM, poultry offal meal plus feather meal; OM, poultry offal meal; and VEG, strictly vegetal control treatment, with corn (Zea mays) and soybean (Glycine max) meal. 
al. (2008), the $\delta^{13} \mathrm{C}$ and $\delta^{15} \mathrm{~N}$ enrichment, responsible for this differentiation, prevented distinguishing among the treatments with the different animal meals $(p>0.05)$. In the yolk samples, the first component caused a greater separation between treatments $(77.60 \%)$ and was more affected by carbon $(0.950)$ than the second component (22.40\%).

Albumen analysis also allowed differentiating $(p<0.01)$ between the vegetable control and the animal meal treatments (Figure 2). The albumen samples showed the best grouping of principal components and the greatest separation between treatments. In the albumen samples, the first component caused a greater treatment separation $(78.10 \%)$ and was more influenced by carbon ( 0.782$)$ than the second component $(21.90 \%)$. This ${ }^{13} \mathrm{C}$ and ${ }^{15} \mathrm{~N}$ isotope enrichment is consistent with the findings of Carrijo et al. (2006), Mori et al. (2007, 2008, 2013), Denadai et al. (2008), Gottmann (2008), Oliveira et al. (2010), and Cruz et al. (2012), who used animal meal in the diets of broilers and Japanese quail.

The isotopic analysis of the egg and its fractions (yolk and albumen) allowed detecting when animal meals were used in the diets of Japanese quail. According to Hobson (1995), for this evaluation, it is advisable to remove yolk lipids and then the whole egg lipids because their content in several tissues can vary among individuals. However, this step of the process was eliminated in the present study, reducing the cost and time of the analysis. The reason for this was the use of albumen, which, due to its low lipid content, does not need to be defatted and is more suitable for this type of analysis. The obtained results are indicative that the $\delta^{13} \mathrm{C}$ and $\delta^{15} \mathrm{~N}$ stable isotope technique is a promising tool for animal product traceability and certification.

\section{Conclusion}

The stable carbon $\left(\delta^{13} \mathrm{C}\right)$ and nitrogen $\left(\delta^{15} \mathrm{~N}\right)$ isotope technique is an effective tool for the traceability and certification of products of animal origin, allowing to detect the use of animal meal in Japanese quail (Coturnix coturnix japonica) diets by the analysis of whole eggs and their fractions (yolk and albumen).

\section{Acknowledgments}

To Fundação de Amparo à Pesquisa do Estado de São Paulo (Fapesp), for financial support (project numbers 2008/57411-4 and 2017/04994-1).

\section{References}

BERTECHINI, A.G. Situação atual e perspectivas para a coturnicultura no Brasil. In: IV Simpósio Internacional, 4.; Congresso Brasileiro de Coturnicultura, 3., 2010, Lavras. Anais. Lavras: UFLA, 2010.

BOTTERO, M.T.; DALMASSO, A. Animal species identification in food products: evolution of biomolecular methods. The Veterinary Journal, v.190, p.34-38, 2011. DOI: https://doi.org/10.1016/j.tvj1.2010.09.024.

CARRIJO, A.S.; PEZZATO, A.C.; DUCATTI, C.; SARTORI, J.R.; TRINCA, L.; SILVA, E.T. Traceability of bovine meat and bone meal in poultry by stable isotope analysis. Brazilian Journal of Poultry Science, v.8, p.63-68, 2006. DOI: https://doi.org/10.1590/S1516-635X2006000100010.

CRAIG, H. The geochemistry of the stable carbon isotopes. Geochimica et Cosmochimica Acta, v.3, p.53-92, 1953. DOI: https://doi.org/10.1016/0016-7037(53)90001-5.

CRUZ, V.C.; ARAÚJO, P.C.; SARTORI, J.R.; PEZZATO, A.C.; DENADAI, J.C.; POLYCARPO, G.V.; ZANETTI, L.H.; DUCATTI, C. Poultry offal meal in chicken: traceability using the technique of carbon $\left({ }^{13} \mathrm{C} /{ }^{12} \mathrm{C}\right)$ and nitrogen $\left({ }^{15} \mathrm{~N} /{ }^{14} \mathrm{~N}\right)$ stable isotopes. Poultry Science, v.91, p.478-486, 2012. DOI: https://doi.org/10.3382/ps.2011-01512.

DENADAI, J.C.; DUCATTI, C.; SARTORI, J.R.; PEZZATO, A.C.; MÓRI, C.; GOTTMANN, R.; MITUO, M.A.O.; BORDINHON, A.M. The traceability of animal meals in layer diets as detected by stable carbon and nitrogen isotope analyses of eggs. Brazilian Journal of Poultry Science, v.10, p.189-194, 2008. DOI: https://doi.org/10.1590/S1516-635X2008000300010.

DENIRO, M.J.; EPSTEIN, S. Influence of diet on the distribution of carbon isotopes in animals. Geochimica et Cosmochimica Acta, v.42, p.495-506, 1978. DOI: https://doi.org/10.1016/00167037(81)90244-1.

EUROPEAN UNION. Regulation (EC) $\mathrm{n}^{\circ} 1069 / 2009$ of the European Parliament and of the Council of 21 October 2009 laying down health rules as regards animal by-products and derived products not intended for human consumption and repealing Regulation (EC) $n^{\circ}$ 1774/2002 (Animal by-products Regulation). Official Journal of the European Union, 14 Nov. 2009. L300.

GOTTMANN, R.; PEZZATO, A.C.; DUCATTI, C.; DENADAI, J.C.; MORI, C.; MITUO, M.A.O.; SARTORI, J.R. Rastreabilidade de subprodutos de origem animal em dietas com levedura e trigo para frangos. Pesquisa Agropecuária Brasileira, v.43, p.1641-1647, 2008. DOI: https://doi.org/10.1590/S0100204X2008001200001.

HENDRIKS, W.H.; BUTTS, C.A.; THOMAS, D.V.; JAMES, K.A.C.; MOREL, P.C.A.; VERSTEGEN, M.W.A. Nutritional quality and variation of meat and bone meal. Asian-Australasian Journal of Animal Sciences, v.15, p.1507-1516, 2002. DOI: https://doi.org/10.5713/ajas.2002.1507.

HERZKA, S.Z.; MELLINK, E.; TALLEY, D.M.; HUXEL G.R.; DAYTON, P.K. Stable isotope ratios of egg albumen of three waterbird species nesting in the Colorado River Delta indicate differences in foraging ground and isotopic niche breadth. Aquatic 
Conservation: Marine and Freshwater Ecosystems, v.23, p.546563, 2013. DOI: https://doi.org/10.1002/aqc.2326.

HOBSON, K.A. Reconstructing avian diets using stable-carbon and nitrogen isotope analysis of egg components: patterns of isotopic fractionation and turnover. The Condor, v.97, p.752-762, 1995. DOI: https://doi.org/10.2307/1369183.

IBGE. Instituto Brasileiro de Geografia e Estatística. 2019. Available at: <www.ibge.gov.br>. Accessed on: Feb. 292020.

MORI, C.; DUCATTI, C.; PIZZOLANTE, C.C.; KAKIMOTO, S.K.; DENADAI, J.C. Traceability of animal meals in Japanese quail eggs using the technique of $13 \mathrm{C} \mathrm{E} 15 \mathrm{~N}^{*}$ stable isotopes. Brazilian Journal of Poultry Science, v.15, p.59-64, 2013. DOI: https://doi.org/10.1590/S1516-635X2013000100010.

MORI, C.; GARCIA, E.A.; DUCATTI, C.; DENADAI, J.C.; GOTTMANN, R.; MITUO, M.A.O. Poultry offal meal traceability in meat quail tissues using the technique of stable carbon $(13 \mathrm{C} / 12 \mathrm{C})$ and nitrogen $(15 \mathrm{~N} / 14 \mathrm{~N})$ isotopes. Brazilian Journal of Poultry Science, v.10, p.45-52, 2008. DOI: https://doi.org/10.1590/S1516-635X2008000100007.

MORI, C.; GARCIA, E.A.; DUCATTI, C.; DENADAI, J.C.; PELÍCIA, K.; GOTTMANN, R.; MITUO, A.O.M.; BORDINHON, A.M. Traceability of animal by-products in quail (Coturnix coturnix japonica) tissues using carbon (13C/12C) and nitrogen (15N/14N) stable isotopes. Brazilian Journal of Poultry Science, v.9, p.263-269, 2007. DOI: https://doi.org/10.1590/S1516$635 X 2007000400010$.

OLIVEIRA, R.P.; DUCATTI, C.; PEZZATO, A.C.; DENADAI, J.C.; CRUZ, V.C.; SARTORI, J.R.; CARRIJO, A.S.; CALDARA, F.R. Traceability of poultry offal meal in broiler feeding using isotopic analysis $(\delta 13 \mathrm{C}$ and $\delta 15 \mathrm{~N})$ of different tissues.
Brazilian Journal of Poultry Science, v.12, p.13-20, 2010. DOI: https://doi.org/10.1590/S1516-635X2010000100002.

PRACHE, S.; CORNU, A.; BERDAGUÉ, J.L.; PRIOLO, A. Traceability of animal feeding diet in the meat and milk of small ruminants. Small Ruminant Research, v.59, p.157-168, 2005. DOI: https://doi.org/10.1016/j.smallrumres.2005.05.004.

ROCK, L. The use of stable isotope techniques in egg authentication schemes: a review. Trends in Food Science \& Technology, v.28, p.62-68, 2012. DOI: https://doi.org/10.1016/j. tifs.2012.04.002.

ROCK, L.; ROWE, S.; CZERWIEC, A.; RICHMOND, H. Isotopic analysis of eggs: evaluating sample collection and preparation. Food Chemistry, v.136, p.1551-1556, 2013. DOI: https://doi.org/10.1016/j.foodchem.2012.03.041.

ROGERS, K.M. Stable isotopes as a tool to differentiate eggs laid by caged, barn, free range, and organic hens. Journal of Agricultural and Food Chemistry, v.57, p.4236-4242, 2009. DOI: https://doi.org/10.1021/jf803760s.

ROSTAGNO, H.S. (Ed.). Tabelas brasileiras para aves e suínos: composição de alimentos e exigências nutricionais. 3.ed. Viçosa: Ed. da Universidade Federal de Viçosa, 2011. 252p.

VINCI, G.; PRETI, R.; TIERI, A.; VIERI, S. Authenticity and quality of animal origin food investigated by stable-isotope ratio analysis. Journal of the Science of Food and Agriculture, v.93, p.439-448, 2013. DOI: https://doi.org/10.1002/jsfa.5970.

WANG, X.; PARSONS, C.M. Effect of raw material source, processing systems, and processing temperatures on amino acid digestibility of meat and bone meals. Poultry Science, v.77, p.834-841, 1998. DOI: https://doi.org/10.1093/ps/77.6.834. 